\begin{abstract}
Iranica
Abstracta Iranica Revue bibliographique pour le domaine irano-aryen

Volume 40-41 | 2019

Comptes rendus des publications de 2017-2018
\end{abstract}

\title{
Aaron Michael Butts, Simcha Gross. The History of the 'Slave Of Christ'. From Jewish Child to Christian Martyr
}

Christelle Jullien

\section{(2) OpenEdition \\ Journals}

Édition électronique

URL : http://journals.openedition.org/abstractairanica/50880

DOI : 10.4000/abstractairanica. 50880

ISBN : 1961-960X

ISSN : 1961-960X

Éditeur :

CNRS (UMR 7528 Mondes iraniens et indiens), Éditions de l'IFRI

\section{Référence électronique}

Christelle Jullien, «Aaron Michael Butts, Simcha Gross. The History of the 'Slave Of Christ'. From Jewish Child to Christian Martyr ", Abstracta Iranica [En ligne], Volume 40-41 | 2019, document 1, mis en ligne le 30 décembre 2019, consulté le 20 avril 2021. URL : http://journals.openedition.org/abstractairanica/ $50880 ;$ DOI : https://doi.org/10.4000/abstractairanica.50880

Ce document a été généré automatiquement le 20 avril 2021.

Tous droits réservés 


\title{
Aaron Michael Butts, Simcha Gross. The History of the 'Slave Of Christ'. From Jewish Child to Christian Martyr
}

\author{
Christelle Jullien
}

\section{RÉFÉRENCE}

Aaron Michael Butts, Simcha Gross. The History of the 'Slave Of Christ'. From Jewish Child to Christian Martyr. (Persian Martyr Acts in Syriac: Text and Translation 6), Piscataway: Gorgias Press, 2017, 269 p. ISBN 978-1-4632-0573-7

1 Ce récit raconte la conversion au christianisme et le martyre consécutif d'un berger juif de 11 ans appelé Asher. Le protagoniste est un jeune garçon appelé à partir de son baptême 'Abda d-Mšiha, " serviteur du Messie ", mis à mort par son père en raison de sa conversion. Ce motif littéraire se retrouve dans d'autres narrations (Behnam et Sarah, Gubralāhā et Qāzō, Sultan Māh-duxt et ses frères par exemple). L'histoire a pour cadre la ville de Singar, dans le nord de la Mésopotamie, aux alentours de 389/390, mais l'on s'accorde pour situer sa rédaction au $\mathrm{VI}^{e}$ siècle. Le narrateur donne le détail intéressant du port d'une boucle d'oreille propre aux esclaves, donné comme signe d'authentique conversion du nouvel esclave du Christ. À propos du tombeau d"Abda probablement édifié en territoire romain oriental, voir l'article de J. M. Fiey dans Le Muséon 77, 1960, p. 205-221 et p. 210-211.

2 Ce texte avait été publié au XIX ${ }^{\mathrm{e}}$ s. par J. Corluy avec traduction latine, "Acta sancti Mar Abdu'l Masich. Aramaice et Latine ", Analecta Bollandiana 5, 1886, p. 5-52. Les AA. offrent ici une première traduction anglaise avec édition critique du syriaque basée sur deux recensions. Il en existe des versions en arménien et en géorgien ainsi qu'en arabe garshouni. Une introduction substantielle d'env. 80 p. présente les conclusions des études antérieures effectuées sur ce texte (essentiellement celles de P. Peeters en 1926 et de J. M. Fiey en 1960) ainsi qu'une réflexion pariculièrement riche et pertinente sur 
les mécanismes d'élaboration littéraire de ce texte, avec un regard très intéressant sur les modèles bibliques et patristiques sous-jacents à la narration, ainsi que sur les relations intercommunautaires entre juifs et chrétiens en milieu babylonien à l'époque tardo-antique. Une bibliographie complète cet ouvrage qui fait désormais référence.

\section{AUTEURS}

\section{CHRISTELLE JULLIEN}

CNRS, Mondes iranien et indien, Paris 